\title{
Effect of the application of probiotic strains of Enterococcus faecium on the physicochemical and sensory characteristics of coalho cheese
}

\section{Efeito da aplicação de cepas probióticas de Enterococcus faecium nas características físico- químicas e sensoriais de queijo coalho}

\begin{abstract}
Tatiane de Oliveira Xavier Machado ${ }^{1 *}$; Roberta Verônica dos Santos Carvalho Mesquita1; Vanicleia Oliveira da Silva2; Micaele Bagagi Araújo3; Anay Priscilla David de Oliveira2; Jane Viana de Souza'; Marcos dos Santos Lima4; Francesca Silva Dias $^{5}$; Rodolfo de Moraes Peixoto ${ }^{4}$
\end{abstract}

\section{Highlights}

Coalho cheeses inoculated with $E$. faecium have 3.5 times more lactic acid.

The strains of $E$. faecium do not change the sensory acceptance of the coalho cheese.

The absence of citric acid suggests production of aromatic compounds by E. faecium.

\begin{abstract}
Coalho cheese is a typical Northeastern Brazilian food whose production and consumption has expanded considerably to other regions of the country. Despite its cultural and socioeconomic relevance, coalho cheese still has a negative reputation due to problems in its physicochemical and microbiological quality standards, especially when it is produced artisanally. For this reason, many researchers have been looking for alternatives to improve the quality and the notoriety of this product, such as the application of probiotic strains to inhibit pathogens. However, in addition to the research related to the desired probiotic properties and the safety of strains for food application, it is important to know the possible changes in the food matrix

1 Mestres, Programa de Pós-Graduação em Ciências Veterinárias no Semiárido, Universidade Federal do Vale do São Francisco, UNIVASF, Petrolina, PE, Brasil. E-mail: tati.o.xavier@gmail.com; roberta.mesquita@ifsertao-pe.edu.br; jhane. viana@gmail.com

2 Mestres, Programa de Pós-Graduação em Ciência Animal, Universidade Federal do Vale do São Francisco, UNIVASF, Petrolina, PE, Brasil. E-mail:priscilladavid.vet@gmail.com; vanicleia.oliveira@ifsertao-pe.edu.br

${ }^{3}$ Eng ${ }^{a}$ Agra ${ }^{a}$ Instituto Federal de Educação, Ciência e Tecnologia do Sertão Pernambucano, IF Sertão, PE, Petrolina, $\mathrm{PE}$, Brasil. E-mail: micaelebagagi63@gmail.com

${ }^{4}$ Profs. Drs., IF Sertão, PE, Petrolina, PE, Brasil. E-mail: marcos.santos@ifsertao-pe.edu.br; rodolfo.peixoto@ifsertao-pe. edu.br

${ }^{5}$ Prof $^{a} \operatorname{Dr}^{a}$, Programa de Pós-Graduação em Ciências Veterinárias no Semiárido, UNIVASF, Petrolina, PE, Brasil. E-mail: francescadiasnobre@gmail.com

Author for correspondence
\end{abstract}

Received: June 05, 2020 - Approved: Oct. 30, 2020 
caused by this intervention. In this context, the aim of this study was to evaluate the effect of the incorporation of probiotic strains of Enterococcus faecium on the physicochemical and sensory characteristics of coalho cheese. The cheeses were made with pasteurized cow milk and probiotic strains of E. faecium were added during production. Cheeses were also made without adding the strains, and considered as control cheeses. The final products were evaluated for moisture, $\mathrm{pH}$, titratable acidity, total carbohydrates, proteins, lipids, ash, color, organic acid profile, and sensory attributes. In addition, viable lactic acid bacteria were also assessed. Coalho cheeses containing $E$. faecium showed higher titratable acidity and lower $\mathrm{pH}$. In addition, there was a reduction in the carbohydrate content, which was attributed to lactose degradation. The organic acid profile also varied, as highlighted by the increase in the concentration of lactic acid by a factor of 3.5 , and by the absence of citric acid as a possible result of the metabolism of E. faecium in the production of aromatic compounds. There was no variation in the color or sensory acceptance of the cheeses. Therefore, the application of probiotic strains of E. faecium in coalho cheese production changes some physicochemical characteristics while maintaining essential properties, such as the color and sensory acceptability of the final product.

Key words: Dairy product. Probiotics. Sensory analysis.

\section{Resumo}

O queijo coalho é um queijo típico do Nordeste do Brasil, cuja produção e consumo se expandiram consideravelmente para outras regiões do país. Apesar de sua relevância cultural e socioeconômica, o queijo coalho apresenta uma reputação negativa, devido a problemas em seus padrões de qualidade físicoquímicos e microbiológicos, principalmente quando é produzido artesanalmente. Por esse motivo, muitos pesquisadores têm buscado alternativas para melhoria da qualidade e notabilidade desse produto, como a aplicação de cepas probióticas que inibem patógenos. No entanto, além da investigação relacionada às propriedades probióticas desejadas e de segurança das cepas para aplicação em alimentos, é importante conhecer as possíveis alterações na matriz alimentícia em virtude dessa adição. Nesse contexto, o objetivo deste estudo foi avaliar o efeito da incorporação de cepas probióticas de Enterococcus faecium nas características físico-químicas e sensoriais de queijo coalho. Os queijos foram elaborados com leite de vaca pasteurizado e adicionados de cepas probióticas de E. faecium durante a produção. Também foram elaborados queijos sem adição das cepas, considerados queijos controle. Os produtos finais foram avaliados quanto a umidade, $\mathrm{pH}$, acidez titulável, carboidratos totais, proteínas, lipídios, cinzas, cor, perfil de ácidos orgânicos e atributos sensoriais. Além disso, procedeu-se a contagem de bactérias ácido lácticas viáveis. Os queijos coalho adicionados de E. faecium apresentaram maior acidez titulável e menor pH. Além disso, houve uma redução no teor de carboidratos, atribuída à degradação da lactose. O. perfil de ácidos orgânicos também variou, destacando-se pelo aumento da concentração de ácido láctico em um fator de 3,5 e pela ausência de ácido cítrico, como possível resultado do metabolismo de E. faecium na produção de compostos aromáticos. Não houve variação na cor nem na aceitação sensorial dos queijos. Portanto, a aplicação das cepas probióticas de E. faecium deste estudo na produção de queijos coalho, altera algumas características físico-químicas, mantendo propriedades importantes, tais como cor e aceitabilidade sensorial do produto final.

Palavras-chave: Análise sensorial. Produto lácteo. Probióticos. 


\section{Introduction}

Coalho cheese is a typical cheese type from the Brazilian Northeast region, whose production and consumption has considerably spread to other regions (Sousa et al., 2014). It is characterized by a white-yellowish color, has moderate to high moisture content, slightly acidic odor, and exhibits resistance to melting when heated (Silva et al., 2016). It is mainly commercialized on the beaches of the country where it is served roasted (Soares et al., 2017), with this being the primary means through which the product reaches tourists from several countries.

Despite its relevance in the cultural and socioeconomic context, this dairy product still requires standardization, especially with respect to physicochemical and microbiological aspects. The variation in its obtainment process, coupled with the lack of good manufacturing practices (GMP) in some dairy products, generates low-quality and even microbiologically unsafe products (Barros et al., 2019; Medeiros et al., 2016). The reputation of this cheese is often reported negatively, especially when it is produced artisanally without pasteurization of milk (Castro et al., 2018).

In the search for alternatives to relieve the notoriety of this product, several studies have been conducted to increase its microbiological safety and shelf life. These studies highlight the use of plant extracts with antimicrobial activity (Costa et al., 2020), chitosan coating and incorporation (Barros et al., 2019), and the inclusion of probiotic microorganisms, such as Enterococcus faecium, with antagonistic activity against pathogens (Castro et al., 2018).
Despite its reduced use compared to other lactic acid bacteria, several strains of E. faecium have presented positive and safe results for application in foods, especially cheeses. Studies report their efficiency in inhibiting pathogens such as Staphylococcus aureus (Castro et al., 2018) and Listeria spp. (Schittler et al., 2019; Zommiti et al., 2018). Furthermore, this genus is known to be responsible for the development of flavor and aroma in the maturation process of several cheese types, and is recommended as an adjunct culture (Yerlikaya \& Akbulut, 2019).

In addition to investigations related to the desired probiotic properties, and following all safety guidelines established by the World Health Organization (Food Agriculture Organization of the United Nations/World Health Organization [FAO/WHO], 2002), it is essential to know the possible changes in the food matrix caused by these microorganisms. In this context, this study aimed to evaluate the effect of the incorporation of probiotic strains of Enterococcus faecium on the physicochemical and sensory parameters of coalho cheese.

\section{Material and Methods}

\section{Strains of E. faecium}

Six strains of $E$. faecium from the bacterial collection at the Laboratory of Inspection and Technology of Animal Origin Products - Milk of the Federal University of São Francisco Valley were used in the experiment, with isolates identified as CAP 1, 4, 13, 14, 18, and 19. These isolates were obtained from goat cheeses, identified, and evaluated in vitro for their probiotic characteristics and safety aspects. In addition to meeting the safety requirements for application in foods, 
the strains were characterized by presenting antagonistic activity against the pathogenic strain S QCSA24 of Staphylococcus aureus isolated from cheeses (Castro et al., 2018).

For use in the present study, the probiotic strains were thawed at room temperature $\left( \pm 25^{\circ} \mathrm{C}\right)$, spread into $10 \mathrm{~mL}$ of Man, Rogosa, and Sharpe (MRS) broth, and incubated at $37{ }^{\circ} \mathrm{C}$ for 72 hours. The colonies developed were spread into MRS broth supplemented with $5 \%$ glucose and incubated under the same conditions. After this period, the samples were centrifuged for $10 \mathrm{~min}$ and washed in sterile distilled water, standardized for turbidity analysis as per standard 2 of the McFarland standards (Probac, Brazil), and immediately dispatched for cheese production.

\section{Cheese production}

The cheese production process was performed with six replications. First, the milk was filtered and pasteurized at $65{ }^{\circ} \mathrm{C}$ for $30 \mathrm{~min}$. Afterward, it was cooled to $36^{\circ} \mathrm{C}$ and $50 \%$ calcium chloride $\left(0.5 \mathrm{~mL} \mathrm{~L}^{-1}\right)$ was added, inoculated with the mixture containing the six probiotic strains at the concentration of $6 \mathrm{x}$ $10^{8} \mathrm{CFU} \mathrm{\textrm {mL } ^ { - 1 }}$ (except for the cheese sample without the probiotic), and then liquid rennet was added at $0.9 \mathrm{~mL} \mathrm{~L}^{-1}\left(\mathrm{Ha}-\mathrm{La}^{\circledR}{ }^{\circledR}\right.$, Christian Hansen Ind. \& Com. Ltda., Valinhos, SP, Brazil). The milk mixture was rested for 40 min until coagulation occurred. The curd was then cut into cubes, followed by stirring and drainage. Salt was added $\left(15 \mathrm{~g} \mathrm{~kg}^{-1}\right)$, and the cheese mass was distributed into perforated molds. After ten $\mathrm{min}$, the cheese samples were turned and stored under refrigeration at $10^{\circ} \mathrm{C}$ for $24 \mathrm{~h}$. The cheeses were then unmolded, vacuum-packed, and stored at $10^{\circ} \mathrm{C}$ for later physicochemical and sensory analyses, which were performed eight days after cheese production. The count of lactic acid bacteria was performed 20 days after production, considering that this time extends beyond the shelf-life of the coalho cheese (Ministério da Agricultura, Pecuária e Abastecimento [MAPA], 2001).

\section{Viable count of lactic acid bacteria}

The viable count of lactic acid bacteria (LAB) was determined using the pour plate technique. In this procedure, $25 \mathrm{~g}$ samples from each cheese were diluted in $225 \mathrm{~mL}$ of sterile peptone water, and the mixture was homogenized. Serial dilutions (up to $10^{-5}$ ) were obtained using the same diluent. Aliquots (0.1 $\mathrm{mL}$ ) from each dilution were plated on MRS agar (Acumedia, EUA) and incubated at $37^{\circ} \mathrm{C}$ for $72 \mathrm{~h}$. The results were expressed as colony forming units per gram of sample (CFU g ${ }^{-1}$ ).

\section{Physicochemical and color analyses}

The cheese samples produced were subjected to physicochemical analysis, to determine their moisture, $\mathrm{pH}$, titratable acidity (in ${ }^{\circ}$ Dornic), total carbohydrates, proteins, lipids, and ash content (MAPA, 2006). Furthermore, the samples were subjected to instrumental color analysis using a colorimeter (MiniScan EZ4500L, HunterLab, United States) calibrated with the CIELab system.

\section{Organic acid profile}

For the determination of the organic acid profile of the cheeses, the sample extracts were initially obtained by adapting the 
methodology described by Zeppa, Conterno and Gerbi (2001) and Oliveira et al. (2017). Extraction was performed by adding $10 \mathrm{~mL}$ of ultrapure water to $2 \mathrm{~g}$ of coalho cheese. The mixture was homogenized in a multi-tube vortex mixer for 3 min and centrifuged at 2,060 $\mathrm{g}$ for $15 \mathrm{~min}$. The supernatant was filtered through a membrane with pores of $0.45 \mu \mathrm{m}$ diameter and used for analysis.

Acid quantification was performed using high-performance liquid chromatography (HPLC) (1260 Infinity Agilent Technologies, Santa Clara, USA), according to the method described by Coelho et al. (2018). The separation of organic acids was performed in an $\mathrm{HI}$ column (Plex $\mathrm{H}$ Agilent Technologies; $300 \times 7.7 \mathrm{~mm}$ with $8 \mu \mathrm{m}$ particles) at $65{ }^{\circ} \mathrm{C}$ using $0.009 \mathrm{M}$ sulfuric acid as the mobile phase at a flow rate of $0.7 \mathrm{~mL} \mathrm{~min}$ 1. A diode array detector (DAD) was used for detection at wavelengths ranging from 220 to

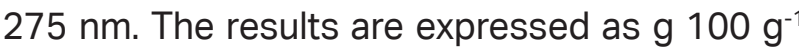
of cheese.

\section{Sensory evaluation}

A 9-point hedonic scale was used for the sensory analysis, with scores ranging from 1 (extremely dislike) to 9 (extremely like), with 5 as the central point (neutral - neither like nor dislike). Cheese samples were evaluated for their appearance, aroma, flavor, texture, and global impression, using 80 untrained tasters of both sexes, aged 18 years or older. The cheese samples were delivered as raw cubes of the same size (not fried or roasted) to the tasters ( $1.5 \mathrm{~cm}$ edge), in a randomized manner. Each taster received two cheese samples, one with and one without the addition of $E$. faecium.
The analysis procedure was previously approved by the Human Research Ethics Committee of the Federal Institute of Education, Science, and Technology of Pernambuco (IF-Sertão), under protocol number 2.257.057.

\section{Statistical analysis}

The results obtained were assessed based on the normality of the data using the Shapiro-Wilk test. The variables for which the data showed normal distribution were subjected to analysis of variance (ANOVA) using the statistical software Sisvar (version 5.6, Brazil). Variables with non-parametric behavior were subjected to the Mann-Whitney test using the SPSS 20.0 software. A significance level of $5 \%$ was considered for all analyses.

\section{Results and Discussion}

The coalho cheese produced with the inoculation of $E$. faecium strains showed a viable count of LAB of $2.2 \times 10^{7} \mathrm{CFU} \mathrm{g}^{-1}$, whereas the control cheese showed a viable count of $5.4 \times 10^{5} \mathrm{CFU} \mathrm{g}^{-1}$, suggesting that the E. faecium strains added to the product might be present even after the shelf life, causing alterations in the cheese considered to be probiotic.

Table 1 shows the results of the physicochemical and color analysis of the cheeses produced. The moisture content was similar in both treatments, without a significant difference ( $p>0.05)$. The observed values are appropriate for coalho cheese as it exhibits moderate to high moisture, containing up to $54.9 \%$ of water (MAPA, 1996). 


\section{Table 1}

Physicochemical characteristics and color parameters of coalho cheese without and with the addition of probiotic strains of Enterococcus faecium

\begin{tabular}{lcc} 
& $\begin{array}{c}\text { Cheese without } \\
\text { E. faecium }\end{array}$ & $\begin{array}{c}\text { Cheese with } \\
\text { E. faecium }\end{array}$ \\
\hline Moisture (\%) & $50.93 \pm 1.53^{\mathrm{a}}$ & $53.90 \pm 1.31^{\mathrm{a}}$ \\
$\mathrm{pH}$ & $6.07 \pm 0.12^{\mathrm{a}}$ & $5.81 \pm 0.03^{\mathrm{b}}$ \\
\hline Acidity ('Dornic) & $17.34 \pm 2.75^{\mathrm{b}}$ & $33.28 \pm 0.97^{\mathrm{a}}$ \\
\hline Carbohydrates $\left(\mathrm{g} 100 \mathrm{~g}^{-1}\right)$ & $3.58 \pm 0.03^{\mathrm{a}}$ & $3.19 \pm 0.17^{\mathrm{b}}$ \\
\hline Proteins $\left(\mathrm{g} 100 \mathrm{~g}^{-1}\right)$ & $14.46 \pm 0.73^{\mathrm{a}}$ & $13.97 \pm 1.54^{\mathrm{a}}$ \\
\hline Lipids $\left(\mathrm{g} 100 \mathrm{~g}^{-1}\right)$ & $18.04 \pm 0.57^{\mathrm{a}}$ & $19.30 \pm 1.03^{\mathrm{a}}$ \\
\hline Ash $\left(\mathrm{g} 100 \mathrm{~g}^{-1}\right)$ & $3.23 \pm 0.17^{\mathrm{a}}$ & $3.08 \pm 0.11^{\mathrm{a}}$ \\
\hline $\mathrm{L}^{*}$ & $93.98 \pm 0.46^{\mathrm{a}}$ & $94.23 \pm 0.11^{\mathrm{a}}$ \\
\hline $\mathrm{a}^{*}$ & $1.68 \pm 0.13^{\mathrm{a}}$ & $1.71 \pm 0.03^{\mathrm{a}}$ \\
\hline $\mathrm{b}^{*}$ & $18.15 \pm 0.21^{\mathrm{a}}$ & $18.44 \pm 0.33^{\mathrm{a}}$
\end{tabular}

Results are presented as the mean \pm standard deviation. Mean followed by the same lowercase letters in the same row do not differ significantly according to the F-test, with $5 \%$ of significance.

The cheese with probiotic exhibited a $\mathrm{pH}$ below that registered for the cheese without the culture $(p<0.05)$. This difference is related to a higher concentration of $\mathrm{H}^{+}$ions, caused by the production of acids from the metabolism of the added strains (Bezerra et al., 2017), which was confirmed by the titratable acidity results. The $\mathrm{pH}$ values observed in this study are in accordance with the results obtained by Sousa et al. (2014), who analyzed coalho cheese samples from six Northeastern Brazilian states (from 5.56 to 6.23 for cheeses made with pasteurized milk).

Another parameter influenced by the addition of $E$. faecium in coalho cheese production was the carbohydrate content, which was reduced. The main carbohydrate present in cheeses is lactose, which lactic acid bacteria use as a fermentation substrate when most of the lactic acid is produced (Matera et al., 2018). Thus, the lower carbohydrate content in the cheese containing the probiotic can be explained by the higher degradation of lactose by lactic acid bacteria.

There was no significant difference between the two cheese samples in terms of the protein content ( $p>0.05$ ). However, in both cases, the protein content observed was considered low. For coalho cheese, the value of this parameter usually exceeds $20 \%$ (Queiroga et al., 2013; Matera et al., 2018). In general, one of the factors that may be related to protein reduction in the cheese mass is the excessive hydrolysis of this component during milk coagulation, releasing soluble peptides that are removed in the whey (Karaca \& Guven, 2018). The addition of $E$. faecium did not change the lipid and ash content of the cheese.

The values of the $L^{*}, a^{*}$, and $b^{*}$ color parameters were similar in both treatments $(p>$ 0.05). The values obtained for $L^{*}$ indicate high lightness, a characteristic of coalho cheese. Similar values were reported by Queiroga et 
al. (2013) when evaluating coalho cheeses produced from cow milk. A trend of cheese coloration towards yellow was also observed through the $b^{*}$ coordinate, depicting the whiteyellowish apparent color of the coalho cheese, as foreseen in its Technical Regulation on Identity and Quality (MAPA, 2001).
The organic acid profiles of the coalho cheese samples quantified using highperformance liquid chromatography (HPLC) are shown in Table 2. The cheese samples without and with $E$. faecium differed statistically ( $p<$ 0.05) in all identified and quantified organic acids.

Table 2

Organic acids (g $\left.100 \mathrm{~g}^{-1}\right)$ present in coalho cheeses without and with the addition of probiotic strains of Enterococcus faecium

\begin{tabular}{lcc} 
Organic acids & $\begin{array}{c}\text { Cheese without } \\
\text { E. faecium }\end{array}$ & $\begin{array}{c}\text { Cheese with } \\
\text { E. faecium }\end{array}$ \\
Lactic acid & $0.176 \pm 0.04^{\mathrm{b}}$ & $0.619 \pm 0.03^{\mathrm{a}}$ \\
Citric acid & $0.059 \pm 0.01$ & - \\
\hline Acetic acid & $0.035 \pm 0.00^{\mathrm{b}}$ & $0.104 \pm 0.00^{\mathrm{a}}$ \\
Formic acid & $0.02 \pm 0.00^{\mathrm{a}}$ & $0.016 \pm 0.00^{\mathrm{b}}$ \\
Succinic acid & - & $0.031 \pm 0.00$
\end{tabular}

Results are presented as the mean \pm standard error. Mean followed by the same lowercase letters in the same row do not differ significantly according to the F-test, with $5 \%$ of significance.

The production of lactic acid observed in the cheese with $E$. faecium was 3.5 times higher than that of cheese without the probiotic. Lactic acid is usually the most important and abundant acid in cheese. It is found in all cheese types, although at various concentrations, as a result of the transformation of glucose and galactose through microbial metabolism (Tofalo et al., 2015). The concentration of this acid tends to increase right from the production to the end of the shelf life of the cheese and is related to the species of lactic bacteria involved in the production process (Bezerra et al., 2017).

Citric acid was observed only in the cheese without $E$. faecium, at a concentration of $0.059 \mathrm{~g} 100 \mathrm{~g}^{-1}$. This acid is naturally present in milk as the citrate ion (Bamidele
\& Adejumo, 2012), but its concentration in cheese decreases throughout maturation. Its absence in the cheese with the probiotic is related to the metabolism of citrate by $E$. faecium, which occurs due to the fermentation of citrate, obtaining pyruvate, finally leading to the production of diacetyl, acetoin, and 2,3 butanediol aromatic compounds. The first two compounds lend a buttery aroma to the cheese (Martino, Quintana, Espariz, Blancato, \& Magni, 2016).

The presence of acetic acid was verified in both the treatments at low concentrations, and was higher in the probiotic cheese. This is due to the heterofermentative characteristics of $E$. faecium, whose metabolism acts distinctly to produce acetic acid in addition to lactic acid (Rodrigues et al., 2011). 
The means of the sensory evaluation scores are shown in Table 3. The samples differed $(p<0.05)$ only in terms of the appearance, with the best scores obtained by the control cheese. This attribute is considered one of the most important in the acceptance of any food since it is the first evaluation made by customers before ingestion. Despite the difference verified, the cheese inoculated with E. faecium was well accepted, ranking between "like slightly" and "like very much." The customer' s behavior regarding preferences for coalho cheese traits involves several observations, including color, brightness, presence of apparent holes, oiliness, moisture, and texture (Soares et al., 2017). Further studies are required to better understand the influence caused on cheese appearance by the addition of strains of $E$. faecium. The behavior of the cheeses after cutting and during consumption, for example, should be evaluated to investigate phenomena such as syneresis.

Table 3

Means of the scores obtained in the sensory analysis of the coalho cheese without and with the addition of probiotic strains of Enterococcus faecium

\begin{tabular}{|c|c|c|c|c|c|}
\hline Samples & Appearance & Aroma & Flavor & Texture & $\begin{array}{c}\text { Global } \\
\text { impression }\end{array}$ \\
\hline $\begin{array}{l}\text { Cheese without } \\
\text { E. faecium }\end{array}$ & $7.92 \pm 0.97^{a}$ & $7.26 \pm 1.38^{a}$ & $7.14 \pm 1.71^{a}$ & $7.43 \pm 1.60^{\mathrm{a}}$ & $7.35 \pm 1.52^{\mathrm{a}}$ \\
\hline $\begin{array}{l}\text { Cheese with } \\
\text { E. faecium }\end{array}$ & $7.50 \pm 1.26^{b}$ & $6.80 \pm 1.65^{a}$ & $6.90 \pm 1.75^{a}$ & $7.24 \pm 1.76^{a}$ & $7.30 \pm 1.49^{a}$ \\
\hline
\end{tabular}

The addition of probiotic strains to the cheese did not influence its acceptance with respect to aroma, flavor, texture, and global impression, considering that the last parameter represented all others. These parameters received average scores around 7, which corresponds to the evaluation "like moderately" on the scale applied. In a study by Sarantinopoulos, Kalantzopoulos and Tsakalidou (2002), the addition of E. faecium strains in the production of Feta Greek cheese was found to be sensorially viable; in this case, besides not affecting the cheese negatively, there was an improvement in the aroma, flavor, and color characteristics of the cheese after maturation. The maintenance or improvement of sensory acceptability is a great challenge in the food industry when modifying formulations or processes, even if functional characteristics are added to the product and benefit the customer (Piqueras-Fiszman \& Spence, 2015).

\section{Conclusions}

The addition of strains of $E$. faecium with probiotic potential in coalho cheese production generated a product with higher titratable acidity, lower $\mathrm{pH}$, and a marked organic acid profile while maintaining important traits, such as color and sensory acceptability. 


\section{Acknowledgments}

We would like to thank the IF Sertão-PE and UNIVASF for the availability of material and human resources during the experiment.

\section{References}

Bamidele, O., \& Adejumo, I. O. (2012). Variability of citric acid in cow milk composition. International Journal of AgriScience, 2(3), 192-199.

Barros, D. M., Moura, D. F., Rocha, T. A., Santos, A. E. S., Silva, M. R. O., Ferreira, S. A. O., Fonte, R. A. B., \& Machado, E. C. L. (2019). Coalho cheese with incorporated chitosan and as a coating: effect on the viability of Staphylococcus aureus and sensory acceptance. Semina: Ciências Agrárias, 40(6), 3477-3492. doi: 5433/1679-0359.2019v40n6Supl3p3477

Bezerra, T. K. A., Arcanjo, N. M. O., Garcia, E. F., Gomes, A. M. P., Queiroga, R. C. R. E., Souza, E. L., \& Madruga, M. S. (2017). Effect of supplementation with probiotic lactic acid bacteria, separately or combined, on acid and sugar production in goat 'coalho' cheese. LWT - Food Science and Technology, 75, 710-718. doi: 10.1016/j. Iwt.2016.10.023

Castro, R. C. S., Oliveira, A. P. D., Souza, E. A. R., Correia, T. M. A., Souza, J. V., \& Dias, F. S. (2018). Lactic acid bacteria as biological control of Staphylococcus aureus in goat "coalho" cheese. Food Technology and Biotechnology, 56(3), 431-440. doi: 10.17113/ftb.56.03.18.5736

Coelho, E. M., Padilha, C. V. S., Miskinis, G. A., Sá, A. G. B., Pereira, G. E., Azevêdo, L. C., \& Lima, M. S. (2018). Simultaneous analysis of sugars and organic acids in wine and grape juices by HPLC: method validation and characterization of products from northeast Brazil. Journal of Food Composition and Analysis, 66, 160-167. doi: 10.1016/j.jfca.2017.12.017

Costa, C. F., Fusieger, A., Andretta, M., Camargo, A. C., Carvalho, A. F., Menezes, D. R., \& Nero, L. A (2020). Short communication: Potential use of passion fruit (Passiflora cincinnata) as a biopreservative in the production of coalho cheese, a traditional Brazilian cheese. Journal of Dairy Science, 103(4), 3082-308. doi: 10.3168/jds.201917791

Food Agriculture Organization of the United Nations/World Health Organization (2002). Joint FAO/WHO working group report on drafting guidelines for the evaluation of probiotics in food. Recuperado de http:// www.fao. org/3/a-a0512e.pdf

Karaca, O. B., \& Guven, M. (2018). Effects of proteolytic and lipolytic enzyme supplementations on lipolysis and proteolysis characteristics of white cheeses. Foods, 7(8), 125, 2018. doi: $10.3390 /$ foods 7080125

Martino, G. P., Quintana, I. M., Espariz, M., Blancato, V. S., \& Magni, C. (2016). Aroma compounds generation in citrate metabolism of Enterococcus faecium: genetic characterization of type I citrate gene cluster. International Journal of Food Microbiology. 218(2), 27-37. doi: 10.1016/j.jjfoodmicro.2015.11. 004

Matera, J., Luna, A. S., Batista, D. B., Pimentel, T. C., Moraes, J., Kamimura, B. A., Ferreira, M. V. S., Silva, H. L. A., Mathias, S. P., Esmerino, E. A., Freitas, M. K., Raices, R. S. L., Quitério, S. L., Sant'Ana, A. S., Silva, M. C. \& Cruz, A. G. (2018). Brazilian cheeses: a survey covering physicochemical characteristics, mineral content, fatty 
acid profile and volatile compounds. Food Research International, 108, 18-26. doi: 10.1016/j.foodres.2018.03.014

Medeiros, R. S., Araújo, L. M., Queiroga, V., Neto, Andrade, P. P., Melo, M. A., \& Gonçalves, M. M. B. P. (2016). Identification of lactic acid bacteria isolated from artisanal Coalho cheeseproducedintheBrazilianNortheast. CyTA - Journal of Food, 14(4), 613-620. doi: 10.1080/19476337.2016.1185468

Ministério da Agricultura, Pecuária e Abastecimento (1996). Portaria $n^{\circ} 146$ de 07 de março de 1996. Regulamentos técnicos de identidades e qualidades de produtos Lácteos.

Ministério da Agricultura, Pecuária e Abastecimento (2001). Instrução Normativa $n^{\circ} 30$ de 26 de junho de 2001. Regulamentos técnicos de identidade e qualidade de manteiga da terra ou manteiga de garrafa, queijo de coalho e queijo de manteiga.

Ministério da Agricultura, Pecuária e Abastecimento (2006). Instrução normativa $n^{\circ} 68$, de 12 dezembro de 2006. Oficializa os Métodos Analíticos Oficiais Físico-Químicos, para Controle de Leite e Produtos Lácteos.

Oliveira, D., Vidal, L., Ares, G., Walter, E. H. M., Resenthal, A., \& Eliza, R. (2017). Sensory, microbiological and physicochemical screening of probiotic cultures for the development of non-fermented probiotic milk. LWT - Food Science and Technology, 79, 234-241. doi: 10.1016/j. Iwt.2017.01.020

Piqueras-Fiszman, B., \& Spence, C. (2015). Sensory expectations based on productextrinsic food cues: an interdisciplinary review of the empirical evidence and theoretical accounts. Food Quality and Preference, 40, 165-179. doi: 10.1016/j. foodqual.2014.09.013
Queiroga, R. D. C. R. D. E., Santos, B. M., Gomes, A. M. P., Monteiro, M. J., Teixeira, S. M., Souza, E. L., Pereira, C. J. D., \& Pintado, M. M. E. (2013). Nutritional, textural and sensory properties of Coalho cheese made of goats', cows' milk and their mixture. LWTFood Science and Technology, 50(2), 538544. doi: 10.1016/j.Iwt. 2012.08.011

Rodrigues, D., Rocha-Santos, T. A. P., Pereira, C. I., Gomes, A. M., Malcata, F. X., \& Freitas, A. C. (2011). The potential effect of FOS and inulin upon probiotic bacterium performance in curdled milk matrices. Food Science and Technology, 44(1), 100108. doi: 10.1016/j.Iwt.2010.05.021

Sarantinopoulos, P., Kalantzopoulos, G., \& Tsakalidou, E. (2002). Effect of Enterococcus faecium on microbiological, physicochemical and sensory characteristics of Greek Feta cheese. International JournalofFood Microbiology, 76(1-2), 93-105. doi: 10.1016/s01681605(02)00021-1

Schittler, L., Perin, L. M., Lima, M. J., Lando, V., Todorov, S. D., Nero, L. A., \& Silva, W. P. (2019) Isolation of Enterococcus faecium, characterization of its antimicrobial metabolites and viability in probiotic Minas Frescal cheese. Journal of Food Science and Technology, 56, 5128-5137. doi: 10.1007/s13197-019-039 85-2

Silva, R. A., Bezerra, V. S., Pimentel, M. C. B., Porto, A. L. F., Cavalcanti, M. T. H., \& Luiz, J., F. (2016). Proteomic and peptidomic profiling of Brazilian artisanal 'Coalho' cheese. Journal of the Science of Food and Agriculture, 96(13), 4337-4344. doi: 10.1002/jsfa.7640

Soares, E. K. B., Esmerino, E. A., Ferreira, M. V. S., Silva, M. A. A. P., Freitas, M. Q., \& Cruz, M. G. (2017). What are the cultural effects on consumers' perceptions? A case study covering coalho cheese in the 
Brazilian northeast and southeast area using word association. Food Research International, 102, 553-558. doi: 10.1016/j. foodres.2017.08.053

Sousa, A. Z. B., Abrantes, M. R., Sakamoto, S. M., Silva, J. B. A., Lima, P. O., Lima, R. N., Rocha, M. O. C. \& Passos, Y. D. B. (2014). Physicalchemical and microbiological aspects of the rennet cheese sold in the Northeast States of Brazil. Arquivos do Instituto Biológico, 81(1), 30-35. doi: 10.1590/ S1808-16572014 000100006

Tofalo, R., Schirone, M., Fasoli, G., Perpetuini, G., Patrignani, F., Manetta, A. C., Lanciotti, R., Corsetti, A., Martino, G., \& Suzzi, G. (2015). Influence of pig rennet on proteolysis, organic acids content and microbiota of Pecorino di Farindola, a traditional Italian ewe's raw milk cheese. Food Chemistry, 175, 121-128. doi: 10.1016/j. foodchem.2014.11.088
Yerlikaya, O., \& Akbulut, N. (2019). Potential use of probiotic Enterococcus faecium and Enterococcus durans strains in Izmir Tulum cheese as adjunct culture. Journal of Food Science and Technology, 56(4), 2175-2185. doi: 10.1007/s13197-01903699-5

Zeppa, G., Conterno, L., \& Gerbi, V. (2001). Determination of organic acids, sugars, diacetyl and acetoin in cheese by highperformance liquid chromatography. JournalofAgriculturalandFoodChemistry, 49(6), 2722-2726. doi: 10.1021/jf0009403

Zommiti, M., Cambronel, M., Maillot, O., Barreau, M., Sebei, K., Feuilloley, M., Ferchichi, M., \& Connil, N. (2018). Evaluation of probiotic properties and safety of Enterococcus faecium isolated from artisanal Tunisian meat "Dried Ossban". Frontiers in Microbiology, 9, 168. doi: 10.3389/ fmicb.2018.0168 
